\title{
Options for the 80s: Directions in Academic and Research Libraries
}

\begin{abstract}
Libraries are remarkably responsive organizations that have adapted and changed substantially over the years. Major changes have occurred in collection development, service programs, bibliographic control, professional standards, and in operational responses to new technology and changes in publication methods. The overall pattern of change has been gradual, and it has been stabilized by well-established institutional routines. More changes lie before us, particularly in the areas of professional staff performance, relations with our parent institutions, and directions in collection development. Our effectiveness will be measured by how we address these issues.
\end{abstract}

Devine, si tu peux, et choisis, si tu l'oses.Corneille.

(Guess, if you can, and choose, if you dare.)

VER THE NEXT DECADE or two, academic and research libraries either will get better or worse. They will not remain the same. Libraries will change; that is inevitable. The principle matter before us as we contemplate the 1980s and look ahead to the next century - less than a generation away - is to identify the options before us. Which options or choices are open? Which ones are closed or have been removed? Are there options or choices we have not yet identified? The choices, or strategic choices to be more precise, are ours to make.

I begin this paper with the quotation, "Guess, if you can, and choose, if you dare." We make these choices; we seek answers to our questions in the face of ambiguity. We make decisions in the face of uncertainty. Ambiguity and uncertainty are a part of our future as they were of our past.

The announcements for this conference emphasize change: "We are in a period of substantial and far-reaching change. Our society is changing. Higher education is changing. The disciplines are changing."1 True enough. What was not said is that libraries,

Beverly P. Lynch is university librarian, University of Illinois at Chicago Circle. too, are changing. Thank goodness. Without the capacity, willingness, and ability to change, organizations-libraries - die.

What is required is that we observe our own libraries and the environments surrounding them. The academic library is shaped by its environment. It is natural and quite appropriate that we wish to learn about that environment, for as Paul Buck, writing a generation ago, emphasized, the proper basis for change is responsiveness. ${ }^{2}$ We need change, not for itself (though in itself change can be revitalizing, at least temporarily), but for the purpose of adapting to new needs and new circumstances.

These needs and circumstances can be of many kinds, stemming from a myriad of sources. The most obvious of these stimuli is, of course, the new technology symbolized by the computer. Rather than adding to the many speculative projections on the impact of technology on the library, however, I have chosen to concentrate upon several general issues of importance to librarianship that place choices or options before us. My emphasis will not surprise you. My emphasis is on the library as an organization. My observation is the library will change as it responds to changes in its environment.

Some of the literature of librarianship suggests that libraries are rigid and inflexible organizations. Our observations and our experiences, however, tell us that academic libraries are remarkably responsive. $\mathrm{Li}$ - 
braries are imaginative in the ways in which they change in response to their environments. Libraries change frequently. Libraries change as they routinely adopt new personnel, new policies, new procedures, new postures.

Since change is a given in libraries, we should realize that most of it comes as a result of relatively stable processes: the application of standard rules and procedures and the rational efforts at problem solving, of trial and error, and of conflict resolution.

We would be delighted if change would occur in sudden, dramatic moments or in one glorious and grand decision. It just doesn't happen that way.

A dwarf sees farther than the giant when he has the giant's shoulders to mount on. - Coleridge.

The history of the past fifty years or so of American academic librarianship is well known and well recorded. Being an amateur in such matters, I will leave the historical discussions and comments to others more able. But let me call to mind the zest, the energy, the excitement we believe now to have characterized our profession during the period of roughly 1925 to 1975 . The founding of the Association of Research Libraries (ARL) in 1932 and the publication of the first issue of ACRL's College o Research Libraries in 1939 are only two indicators of the ferment. As a profession we have taken for granted the influence of ARL in shaping the direction of research librarianship and we have underestimated the impact on the profession of a journal devoted solely to academic and research librarianship.

The efforts of the giants of the profession, Keyes D. Metcalf, director at Harvard, 1937-1955; Robert B. Downs, director at the University of Illinois at Urbana-Champaign, 1938-1971; Frederick H. Wagman, director at the University of Michigan, 1953-1978; Stephen A. McCarthy, director of Libraries, Cornell, 1946-1967; Robert G. Vosper, director, UCLA, 1961-1973; Herman H. Fussler, director, University of Chicago, 1948-1971, and a host of others resulted in extraordinary accomplishments. To be a part of librarianship during this period of expansion, an expansion of such monumental proportion, and to know and work with the people shaping librarianship was very exciting.
It is problematic whether those at the heart of the decision making recognized the change in which they were engaged as they worked each day in the library, met with colleagues, answered the phone and the mail, and tried to interpret their own actions in light of the day's problems. Only in retrospect do we observe the change as being extraordinary and dramatic, coming as it did in a culmination of many small actions and decisions.

Many choices were made by these great librarians, based upon their assessments of their own institution's environment, the requirements of the profession, the influence upon all research libraries of the general expansion of higher education, and the demands of the publication explosion. Colleges and universities and knowledge in general were expanding in ways never before contemplated or experienced.

Scores of libraries in research universities in the U.S. became libraries of the first rank during this period. Our fine college libraries and independent research libraries grew and prospered. During all of the ferment, choices were made to achieve these outcomes. The growth and development of academic libraries in the U.S. since the Second World War has been phenomenal, and the building and shaping of that growth stimulated the profession in ways we are only now assessing. This unparalleled expansion and growth of academic libraries offers a remarkable history.

David Stam is fond of recounting a famous, if apocryphal, story about one of the first conferences of the American Historical Association held away from the East Coast. The AHA was meeting at the University of Wisconsin in the mid-1930s. At one of the cocktail parties a prominent eastern historian asked a distinguished historian from Madison how far east he had to go to reach a good library. The quick reply was the British Museum. Now fifty years later, the response would be quite different. We have superb libraries. Although probably exaggerated, an American librarian has been quoted as saying, "My guess is that the post-war American university library boom will someday be considered as important to the growth of knowledge as the development of the German doctoral disciplines was to research in the 19th century." 3 
We moderns, the old schoolman said, are dwarfs mounted upon the shoulders of giants, able to see so far only because we perch atop the immense bulk of the ancients. Yet, being able to see further than they, sometimes we dwarfs grow contemptuous of the giants, and give them a kick, or aspire to stand in mid-air; and then down we go to the bottom of the ditch. - Russell Kirk.

As a result of past efforts there now are throughout the country collections capable of supporting advanced study and research in every field. There are countless new academic library buildings, some architectural gems, others undistinguished but serviceable, which house these collections.

The selection function, for the most part, has become the responsibility of librarians, not faculty members. The high quality of reference work performed in academic libraries is commented upon in the acknowledgment sections of many treatises and texts and in the countless letters written by grateful students and scholars. The extraordinary accomplishments in the areas of bibliography and bibliographic control are well known. They are of the highest quality. Our libraries are well managed.

The professionalism of the academic librarian, shaped by the growth and development of graduate library education, continues to advance. We have made great strides in turning library work into a profession. In Europe, as a thoughtful observer of the international scene has commented, "the libraries are better than the librarians." 4 That comment could not be made about the United States. Here the academic and research librarians are worthy of the collections and the patrons they serve. Our libraries and our librarians have obtained a common stature.

The accomplishments of the profession are ones of which we are proud. They are ones upon which we can build. We will build upon them slowly and surely, by trial and error, just as the past accomplishments were achieved.

What is ahead? Unprecedented change, of course. Just as the unprecedented change of the post-World War II expansion led to the exemplary responses of librarians and libraries of that time, so are we required to make the proper assessments and the proper responses.
We are in the midst of change. Technological developments have led to revisions in the ways libraries carry out their primary functions, in the ways librarians select and order materials, place these materials under bibliographic control, and carry out reference and circulation services. Libraries now buy services formerly carried out in-house. Can any of us remember the catalog department of ten years ago? It is not the department of today. I don't expect today's department to be that of tomorrow, certainly not of the next century. But the inevitable changes, while dramatic in retrospect and perhaps painful in design, brought about by the changes in the methods we use to handle our production processes, occur in small bits and pieces, in fits and starts.

Since 1970 extraordinary innovations have been introduced in libraries. Those being proposed for the 1980 s perhaps are even more fundamental. During the 1970 s we worried about the introduction of automation in libraries. By the end of the decade automated systems were in place. We now use computerbased information systems in reference services. These information systems identify materials not in our libraries. The systems identify papers often not scrutinized or judged by journal editors nor subjected to decisions based upon the judgments of librarians. These developments will result in greater information overload than we have now the "static," as Oscar Handlin puts it - which makes our task more difficult and more critical.

We expect major changes in the methods of publishing and in the formats of publication. Each of these innovations is growing and developing. Only a few are based in technologies likely to persist over a long period of time; that is, only a few-computer-based circulation control, LC MARC-based computer-generated catalogs, and antitheft devices - are climax technologies. ${ }^{5}$ Other innovations, based in changing or intermediate technologies, continue to grow, develop, and change.

Some environmental changes have been described at this conference:

Thomas Melady indicates that to reduce inflation is the government's goal. If the present rate of inflation in library materials were reduced or controlled, could we quickly 
enough make appropriate changes in our budget justifications?

Robert Rosenzweig observes that government involvement in the research enterprise will continue. He describes that involvement as a dependency, not as a partnership, shaped by the democratic political processes. Are we librarians skilled enough, are we political enough, to operate in this environment?

Daniel Sullivan argues that, at least in the private liberal arts college, libraries will absorb a disproportionate share of the budget cuts. He also points to the inevitable enrollment decline occurring with the demographic shift and suggests an environment of greater and greater institutional competition. How will we respond to an increasingly competitive institutional environment with our programs of sharing every resource regardless of institution. Might these be incompatible goals?

The mark of wisdom is to read aright the present and march with the occasion. - Homer.

I speak to you not as a prophet nor a seer with a crystal ball. Rather I speak from experience as a university librarian who must make daily decisions, and who is compelled to make choices often with insufficient information, little time, and less than a clear vision of how the decision is ultimately implemented. Also I am a student of organizations, so I try to understand the behavior of organizations, fitting my observations into a theoretical structure. In general I believe that organizations, and libraries as organizations, seek to make routine the work done in them. Organizations, and libraries as organizations, continually strive to make complex tasks simple, ambiguous problems obvious. Also I believe that organizations - libraries continuously act in responsive ways to their environments.

Although I speak of change, encourage change, recognize the need for change, and strive for change, it is my view that an effective library, adapting in a responsive and sound way to its environment, will have its primary basis for change in systems of routine behavior. That may seem to be antithetical to our need for change. The extraordinary change in libraries occurring during the last decade and in the last thirty years came about in the small, routine decisions that govern the daily affairs of our libraries. The change did not occur in sudden, grand decisions, in a single grand design.

So what are the choices or options before us as we move through this decade toward the next century?

We can choose to hire the best librarians we can find, seeking those who are educated, not in the techniques of today, but in a philosophical and technical base that prepares them to design the techniques of tomorrow. Some libraries will continue to seek librarians who are the skilled technicians. Others will seek the creative, imaginative, ambitious graduates, librarians interested more in a career than in a job.

We can choose to base our professional criteria for appointment, promotion, and security of employment in the daily, on-the-job performance expected of all staff members, or we can ask something more of our professional staff as regards professional growth, research, and publication. It has been estimated that about 15 percent of academic libraries, libraries of all sizes, now require evidence of some kind of professional growth for advancement. Other libraries can choose and will choose to add these criteria to their own.

We can choose to place our well-educated "new hires" into jobs that demand more of them than they can give at first, or we can place them in jobs that may be less than professional. The profession and each academic library continuously seek to define their professional and nonprofessional work. We continue to make routine the librarian's task. Jobs formerly performed by librarians now are performed by paraprofessionals, clerical help, and, in some libraries, by students. At the same time a library makes choices about its present jobs and the skills required for them, it creates new jobs with new required skills. The process is an ongoing one. There never will be a definitive answer as to what is professional work and what is not. Each library will make some choices about that. The basis for choice will be the decision made by each librarian as to what constitutes the professional work he or she does. For the "new hires" the process of job definition may be slower than they would wish. That is an organizational tension likely to continue, given the very nature of organizations. It is a tension that can be creative or destructive de- 
pending upon the situation.

We can choose goals and objectives for our libraries. The traditional goal of the academic library, and a goal to which we all still subscribe, is that the library serve the goals and objectives of the institution of which it is a part. In seeking cooperative solutions to some matters relating to bibliographic control and access, we have tended to assume that all academic libraries are driven by the same goals and objectives, thereby assuming by extension that all colleges and universities also are driven by the same goals and objectives. In making such assumptions we may have weakened the traditional goal of the academic library, removing it from its immediate environment and placing it in a more general and less localized context. What I am trying to suggest here is that it may be unwise for us to ignore the intense competition that may exist between or among institutions competition for students, for operating capital, for research dollars. While striving to achieve a common goal of sharing library resources, some libraries may find that goal surprisingly inconsistent with that of its institution. Sensitivity and careful observation of goals and objectives-are they mutually held? - is required.

We can choose to respect the decisions of other libraries or not. We can expect each library to make its own determination of priorities or not. We can treat those who hold different opinions or make choices different from our own as colleagues or as opponents, either supporting them or attempting some sort of punitive action against them. There has been a tendency in library thinking, when one differs with a decision, to criticize not the decision, but the decision maker; not to attempt to reason a change in opinion or in the priorities of others, but to force a change in them. We can choose to follow this course or not. But each choice or option will influence the future growth and direction of our libraries and ultimately of academic librarianship.

The profession generally agrees upon its national problems: continued exponential growth in recorded literature and information; cost pressures related to inflation, rates of exchange, and college and university budgets; emergence of new and expensive information services; the deterioration of pa- per; and the self-destruction of stock in many libraries are some of them.

The profession does not yet agree on the appropriate or suitable responses to those problems, nor do we agree on how an individual library might respond. Those librarians who continually assess their library's environments, who know the needs of their primary clientele, who have the collections and the methods to meet those needs, who reflect on the future needs and methods, and who have the courage to choose priorities in their best judgment and in the force of incomplete information rather than to guess at priorities, will provide the answers for many of us.

We can choose our collections. These choices may be the most significant of all. The services of libraries have their bases in the collections, so our fundamental interest in collections must continue. Our collections are shaped by the instructional programs and research interests of our institutions. The collections are not shaped in the warehouse of a jobber or in a state office somewhere.

While we work on methods of bibliographic control and access to retrospective collections developed in the past, we are selecting and building the collections that will form the retrospective collections of the future. How will we choose to shape these collections? What judgments will we make? Are we collecting materials today that will go into remote storage collections of tomorrow? In his book Academic Research and Library Resources, ${ }^{6}$ Charles Osburn says this about the library and research:

The scientist is no longer a "scholar"; he is a researcher who pieces together bits of information acquired by whatever means is the fastest and most efficient, and applies it to a theory and methodology of his own creation. In this cycle, the purpose of publication is more often the establishment of historical record and precedence than the communication of information so that the maintenance of large local collections of scientific literature may be more politically motivated than substantively motivated.

About the social sciences, Osburn comments:

Far from being the heart of a research activity in the social sciences, the library, as a collection of books and journals, constitutes only one of the many tools used by the social scientist. . . . With 
the exception of a small core of journals, monographic works that summarize research progress in specific disciplines, and statistical compilations, printed materials in the social sciences constitute a useful historical record of achievement, but otherwise are of little immediate value to research.

Do these general observations match what we observe on our own campuses? Should we base our own library's collection development policies on them? What might determine differences? How does the library identify differences and respond to them? These questions require careful and deliberate responses. The answers should lead to careful and deliberate choices and decisions. They will lead to diversity in collections. Every library has these questions before it.

The zest, energy, and excitement of the past are here today. Those who follow us and will reflect on the period from 1975 to 2000 surely will marvel at our accomplishments. We who are shaping those accomplishments will not see the results of our efforts as easily. Our decisions are built upon the stable processes found in all libraries. Organizational change comes slowly, but it does come.

The effectiveness of our libraries will be determined by the decisions we make about who is to staff them, the choices we make in establishing criteria for appointment and promotion, and the abilities we have in assessing the growth and development of our librarians.

The match or the fit between the library's goals and objectives and the goals and objec- tives of the college or university it serves will shape the library's overall effectiveness. The interests and requirements of the primary clientele (are those requirements accurately identified, are methods and techniques for serving our patrons available, can we assess future needs?) and responses to those interests and requirements will determine our effectiveness. The understanding of our library environments and an awareness of the variety in goals and objectives are central components.

Those choices made daily by various librarians in our libraries, that is, the selection of materials we add to our collections, perhaps form the most critical choices of all. The excellence of the selection decision, infinitely more complicated now by the sheer volume of materials available, the reduction in peer review and scholarly judgment prior to publication, and the expanding boundaries of the disciplines, will lead to the retrospective collections to be used by scholars in the next century. The continuing excellence of our libraries will depend upon the choices made with regard to collection development and acquisitions.

As a profession we have the knowledge, skill, and ability to determine the direction of our future. Our libraries and our librarians will make the critical choices. We cannot guess. We must choose, knowing full well the hazards and difficulties. Choice is never easy; it also is never dull. I am confident that we will choose wisely and choose well.

\section{REFERENCES}

1. College \& Research Libraries News 12:220 (July/Aug. 1981).

2. Paul Buck, "Responsiveness," in Edwin E. Williams, ed., Libraries \& Universities, Addresses and Reports (Cambridge, Mass.: Belknap, 1964), p.63-67.

3. William J. Welsh, in Gordon N. Ray, "A Retrospective View," in Edward Connery Lathem, ed., American Libraries as Centers of Scholarship (Hanover, N.H.: Dartmouth College, 1978), p. 21 .
4. Herman Liebaers, in Ray, "A Retrospective View," p.18.

5. Malcolm Getz, Public Libraries: An Economic View (Baltimore, Md.: Johns Hopkins Pr., 1980).

6. Charles Osburn, Academic Research and Library Resources (Westport, Conn.: Greenwood, 1979), p.49, 61 . 